\title{
Removal of Metals from Aqueous Solutions Using Sea Buckthorn Waste from Dietary Supplement Technology
}

\author{
Lidia Kim $^{1}{ }^{1}$, Gina-Alina Catrina (Traistaru) ${ }^{1}$, Georgiana Cernica ${ }^{1}$, Vasile Staicu ${ }^{2}$, Mariana Popescu ${ }^{2}$ and \\ Cristina Ileana Covaliu ${ }^{3, *}$
}

Citation: Kim, L.; Catrina (Traistaru), G.-A.; Cernica, G.; Staicu, V.; Popescu, M.; Covaliu, C.I. Removal of Metals from Aqueous Solutions Using Sea Buckthorn Waste from Dietary

Supplement Technology.

Sustainability 2021, 13, 1441.

https://doi.org/10.3390/su13031441

Academic Editor: Andreas

N. Angelakis

Received: 18 November 2020

Accepted: 25 January 2021

Published: 29 January 2021

Publisher's Note: MDPI stays neutral with regard to jurisdictional claims in published maps and institutional affiliations.

Copyright: (c) 2021 by the authors. Licensee MDPI, Basel, Switzerland. This article is an open access article distributed under the terms and conditions of the Creative Commons Attribution (CC BY) license (https:// creativecommons.org/licenses/by/ $4.0 /)$.
1 National Research and Development Institute for Industrial Ecology_ECOIND, 060652 Bucharest, Romania; lidia.kim@incdecoind.ro (L.K.); gina.catrina@incdecoind.ro (G.-A.C.); georgiana.cernica@incdecoind.ro (G.C.)

2 S.C. Hofigal Export-Import S.A., 042124 Bucharest, Romania; vasile.staicu@yahoo.ro (V.S.); mari.popescu@yahoo.com (M.P.)

3 Faculty of Biotechnical Systems Engineering, University Politehnica of Bucharest, 060042 Bucharest, Romania

* Correspondence: cristina_covaliu@yahoo.com; Tel.: +40-722791791

\begin{abstract}
The purpose of this study was to produce additional data for the valorization process of vegetable waste originating from dietary supplement technology. Two types of vegetable waste originating from different technological processes of sea buckthorn oil were used: vegetable waste from organic solvent extraction (P1) and vegetable waste from cold extraction (P2). Batch experiments evaluated the influence of $\mathrm{pH}$, initial metal concentration, contact time, and Langmuir and Freundlich adsorption isotherms. The following pollutants- $\mathrm{Cu}, \mathrm{Cr}, \mathrm{Co}, \mathrm{Ni}, \mathrm{Pb}$ and $\mathrm{Zn}-$ from the wastewater were studied. The removal efficiency of metals from wastewater was evaluated at $\mathrm{pH} 3,5$ and 7. The highest metals removal efficiency was obtained at $\mathrm{pH}$ 5. It was observed that the Langmuir isotherm fits the adsorption process very well. Based on the results obtained, it can be concluded that vegetable waste resulting from the sea buckthorn oil industry could have potential applications for removing toxic metals from wastewater due to its high removal efficiency $(>80 \%)$.
\end{abstract}

Keywords: adsorbent materials; metals; removal efficiency; vegetable waste; valorization

\section{Introduction}

Pollution of water bodies with heavy metals is a worrying problem nowadays. The importance of removing dissolved heavy metals from water is a concern for society as a whole, as heavy metals pose a risk to human health and environmental protection. Heavy metals are toxic and carcinogenic and can easily enter the food chain.

The adsorption process is influenced by a number of parameters such as the amount of adsorbent, temperature, adsorbent concentration, contact time and $\mathrm{pH}$ of the solution. A greater amount of adsorbent makes possible a higher removal efficiency. This can be attributed to the greater availability of exchangeable sites or surfaces at a higher adsorbent concentration. As the contact time increases, adsorption increases to a certain extent until the equilibrium state is reached and then remains constant [1-7].

One of the most effective techniques for removing heavy metals from aqueous solutions is adsorption because it has high efficiency and economic benefits [7-11]. Heavy metals are considered priority pollutants because they are non-biodegradable and can affect aquatic ecosystems in the long run [12-16]. There are a variety of conventional techniques capable of removing heavy metals from water that have already been successfully tested, such as precipitation, ion exchange, reverse osmosis, membrane separation, adsorption, etc.

According to the Romanian legislation GD No. 352/2005, the Normative regarding the conditions for the discharge of wastewater in natural receptors (NTPA 001/2005), the maximum concentrations allowed for metals are: $0.1 \mathrm{mg} / \mathrm{L} \mathrm{Cu}, 1 \mathrm{mg} / \mathrm{L} \mathrm{Cr}, 1 \mathrm{mg} / \mathrm{L} \mathrm{Co}$, $0.5 \mathrm{mg} / \mathrm{L} \mathrm{Ni}, 0.2 \mathrm{mg} / \mathrm{L} \mathrm{Pb}$ and $0.5 \mathrm{mg} / \mathrm{L} \mathrm{Zn} \mathrm{[17].} \mathrm{Considering} \mathrm{these} \mathrm{legislative} \mathrm{regulations,}$ 
it is necessary to find reliable and low-cost technological solutions for the treatment of wastewater with metal concentrations that exceed the maximum allowed limits.

The use of lignocellulosic vegetable waste as adsorbent material has a number of advantages, such as adsorption being achieved with high efficiency and at low cost, adsorbent materials being biodegradable, and adsorption processes being environmentally efficient, falling into the category of green chemistry. Some examples of using vegetable waste as adsorbent material for retaining heavy metals from different aqueous media are presented in Table 1.

Table 1. Summary of removal efficiency of metals on miscellaneous adsorbent materials.

\begin{tabular}{|c|c|c|c|c|}
\hline $\begin{array}{l}\text { Metal/Analysis } \\
\text { Techniques }\end{array}$ & Adsorbent/Adsorbate Solution & Adsorption Model & Removal Efficiency & Reference \\
\hline $\mathrm{Pb}$ (II)/ICP-EOS & $\begin{array}{c}\text { Rice husk, maize cobs, } \\
\text { sawdust/aqueous solutions }\end{array}$ & $\begin{array}{l}\text { Langmuir } \\
\text { Freundlich } \\
\text { Temkin }\end{array}$ & $\begin{array}{c}99 \% \\
\mathrm{pH} 4.5-6.5\end{array}$ & [1] \\
\hline Cd (II)/ICP-AES & $\begin{array}{l}\text { Pine bark modified with Fenton } \\
\text { reagent/aqueous solutions }\end{array}$ & Langmuir & $97 \%, \mathrm{pH} 7$ & {$[2]$} \\
\hline Cd (II)/ AAS & Maize leaf/dilute solutions & $\begin{array}{l}\text { Freundlich } \\
\text { Langmuir }\end{array}$ & $94.65 \%, \mathrm{pH} 3$ & [18] \\
\hline $\begin{array}{c}\mathrm{Cd}(\mathrm{II}), \mathrm{Cu}(\mathrm{II}), \mathrm{Pb}(\mathrm{II}) \\
\mathrm{Zn}(\mathrm{II}) / \mathrm{AAS}\end{array}$ & $\begin{array}{c}\text { Carpobrotus edulis } \\
\text { particles/industrial wastewater }\end{array}$ & Langmuir & $\begin{array}{l}\mathrm{Cd}(94 \%), \mathrm{Cu}(91 \%), \mathrm{Pb} \\
(99 \%), \mathrm{Zn}(98 \%), \mathrm{pH} 7.67\end{array}$ & {$[3]$} \\
\hline Cd (II) / AAS & $\begin{array}{l}\text { Activated carbon prepared from } \\
\text { olive stone/aqueous solutions }\end{array}$ & $\begin{array}{l}\text { Langmuir } \\
\text { Freundlich }\end{array}$ & $80 \%, \mathrm{pH}>6$ & {$[4]$} \\
\hline $\begin{array}{l}\mathrm{Zn}(\mathrm{II}), \mathrm{Cd}(\mathrm{II}), \mathrm{Mn} \\
\quad \text { (II) / ICP-EOS }\end{array}$ & Maize stalks/aqueous solutions & $\begin{array}{l}\text { Langmuir } \\
\text { Freundlich } \\
\text { Temkin }\end{array}$ & $\begin{array}{l}\mathrm{Zn}(63 \%), \text { pH } 5 \\
\mathrm{Cd}(46 \%), \text { pH } 6 \\
\mathrm{Mn}(38 \%), \text { pH } 7\end{array}$ & [19] \\
\hline
\end{tabular}

The removal of heavy metals from wastewater by adsorption is dependent on the $\mathrm{pH}$ of the solution, a critical parameter because it controls adsorption at the solution-adsorbent material interface and the oxidation state of metal ions [20]. When the $\mathrm{pH}$ value increases, the adsorbent surface is more negatively charged and attracts metal ions with positive charges, thus causing adsorption onto the adsorbent material [20].

The formation of complex hydroxides, carbonates and organic complexes at alkaline $\mathrm{pH}$ leads to a decrease in the availability of metal ions to be adsorbed onto adsorptive material. Extreme $\mathrm{pH}$ values can damage the structure of the adsorbent material, causing cellular distortion and significant mass loss [7,11,21,22].

In recent decades, sea buckthorn (Hippophae rhamnoides), a thorny bush plant grown in Romania, has been considered a real hope for improving human health, due to its nourishing, vitaminic, revitalizing and even healing action. The technological process of extracting sea buckthorn oil produces some vegetable waste that can be recovered instead of being burned $[19,20]$.

The sea buckthorn waste from dietary supplements technology is a natural, lowcost, non-toxic, biodegradable and abundant material. It contains lignin, cellulose and hemicellulose, all of which have adsorptive sites, like carbonyl, carboxyl, and amine and hydroxyl groups, capable of adsorbing metal ions via interactions such as ionic exchange or complexation $[19,20]$.

Thus, this paper presents studies regarding the adsorption of some metals $(\mathrm{Cu}, \mathrm{Cr}$, $\mathrm{Co}, \mathrm{Ni}, \mathrm{Pb}$ and $\mathrm{Zn}$ ) from aqueous solutions using two types of sea buckthorn waste as adsorption materials. Some parameters that influence the adsorption process such as $\mathrm{pH}$, contact time, initial concentration of metals in the solution and the amount of adsorbent were determined. The paper presents a new way of valorizing sea buckthorn waste as an adsorbent material for the depollution of aqueous solutions contaminated with metals. 


\section{Materials and Methods}

\subsection{Materials}

To accomplish the study, two types of vegetable waste (adsorbent materials) from the technological process of obtaining sea buckthorn oil (a dietary supplement) were selected: P1—sea buckthorn vegetable waste from organic solvent extraction of sea buckthorn oil, and P2 - sea buckthorn vegetable waste from cold pressing extraction of sea buckthorn oil (Figures 1 and 2).

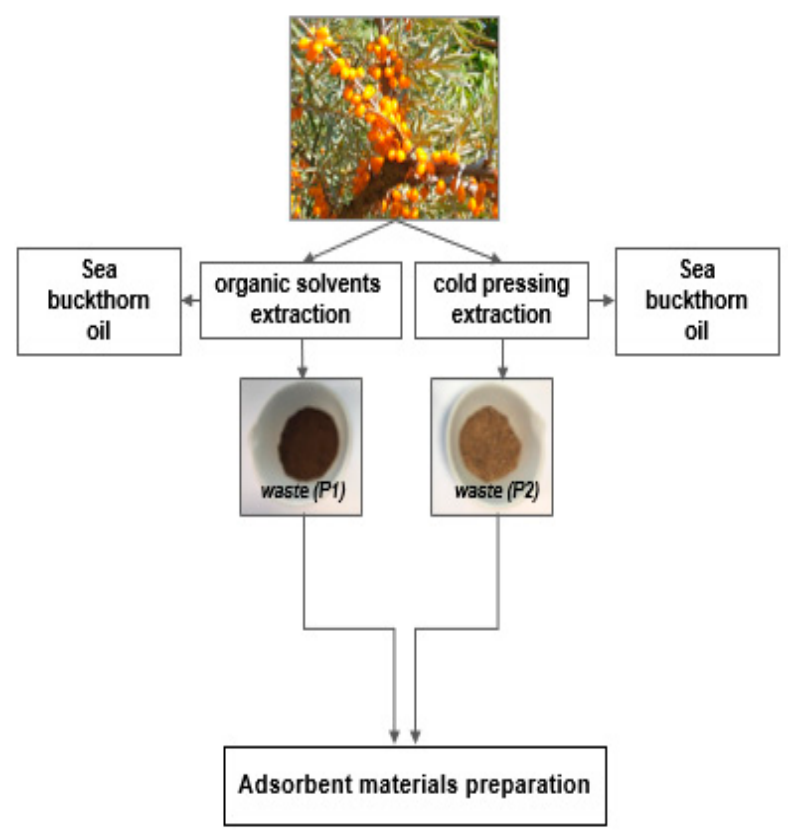

Figure 1. Source of adsorbent materials.

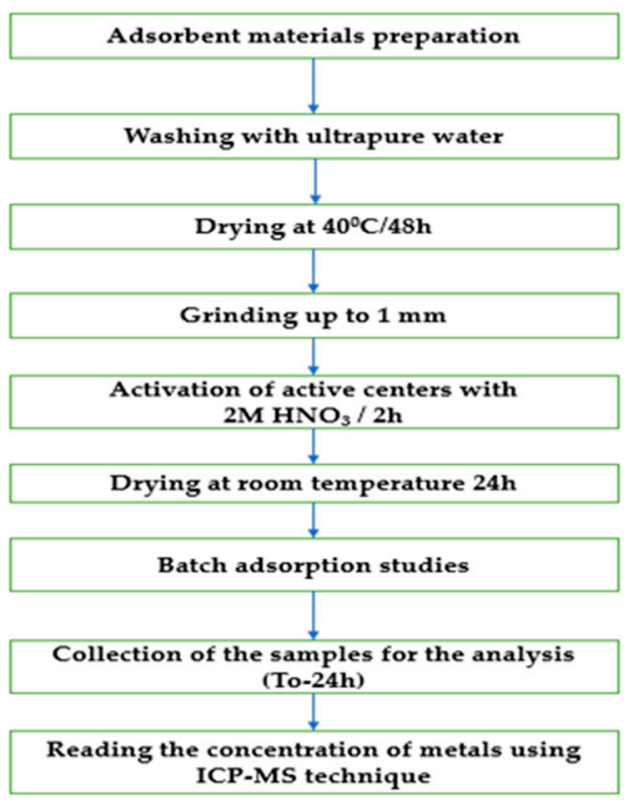

Figure 2. Preparation of new adsorbent materials for testing.

\subsection{Reagents}

All reagents used in this study $\left(\mathrm{HNO}_{3}, \mathrm{H}_{2} \mathrm{O}_{2}, \mathrm{NaOH}\right)$ were of analytical grade and purchased from Sigma Aldrich (Munich, Germany). Ultrapure water was produced with a Millipore Milli-Q System. 


\subsection{Materials Characterization}

Metal concentrations were determined with a mass spectrometer with inductively coupled plasma (ICP-MS) using Agilent 7900 equipment with Mass Hunter 4.4 software, in the concentration range $100-500 \mu \mathrm{g} / \mathrm{L}$. For the calibration curves, a multielement certified reference material was used (1000 mg/L ICP multielement standard solution XXI, Certipur, Merck). Quality control of the analytical results was performed with multielement certified reference material for ICP (100 mg/L, Merck quality). For each sample, threefold determination was performed, and the concentration obtained was the average of three determinations.

FTIR-ATR analysis was carried out using Perkin Elmer Spectrum TwoTM equipment. Attenuated total reflection (ATR) is a sampling technique used in conjunction with infrared spectroscopy (FTIR), which enables samples to be examined directly in the solid state without further preparation. FTIR-ATR spectroscopy has high potential for investigating a wide range of samples and systems. The working range for both samples was $650-4000 \mathrm{~cm}^{-1}$.

Elemental analysis, to determine the carbon, nitrogen and hydrogen content, was performed using a chromatographic method on a Thermo Scientific Flash EA 1112 Elemental Analyzer. The Elemental Analyzer is based on the well-known flash dynamic combustion method, which produces complete combustion of the sample within a high temperature reactor, followed by accurate and precise determination of the elemental gases produced $\left(\mathrm{N}_{2}, \mathrm{CO}_{2}, \mathrm{H}_{2} \mathrm{O}\right.$ and $\left.\mathrm{SO}_{2}\right)$, using a thermal conductivity detector. The sample combustion temperature was $950^{\circ} \mathrm{C}$. Determination of moisture content was performed by gravimetric methods.

\subsection{Analytical Method}

\subsubsection{Acid Treatment of Adsorbent Material}

In order to convert vegetable waste into adsorbent materials, the samples must be prepared in several stages, as described in Figures 1 and 2. To obtain the active centers of the adsorbent materials, the samples were dried at $40{ }^{\circ} \mathrm{C}$ and crushed to a $1 \mathrm{~mm}$ particle size. Then, the samples were activated by soaking them in $2 \mathrm{M} \mathrm{HNO}_{3}$ for $2 \mathrm{~h}$. Afterwards, they were washed with water and dried at room temperature for $24 \mathrm{~h}$.

Figures 1 and 2 present the source of adsorbent materials and the preparation process of adsorbent materials for testing.

\subsubsection{Batch Adsorption Studies}

From the results obtained from the literature, it was found that the wastewater treatment efficiency of metals from aqueous solutions can be improved via treatment with acids and bases by changing the initial $\mathrm{pH}$ of the working solutions $[1-4,7,18]$. Based on the literature, the batch studies in this paper were performed at $\mathrm{pH} 3,5$ and $7[1-4,7,18]$. The metal solutions were adjusted to the established $\mathrm{pH}$ value with $0.5 \mathrm{M} \mathrm{HNO}_{3}$ and $0.5 \mathrm{M} \mathrm{NaOH}$.

The parameters studied were: $\mathrm{pH}$ variation $(3,5$ and 7$)$, contact time $(2,4,6,8$ and $24 \mathrm{~h})$, initial metal concentration $(2,4$ and $6 \mathrm{mg} / \mathrm{L})$ and the quantity of adsorbent material $(1 \mathrm{~g}$ and $0.5 \mathrm{~g})$. The wastewater treatment efficiencies of six metals $(\mathrm{Cu}, \mathrm{Cr}, \mathrm{Co}, \mathrm{Ni}, \mathrm{Pb}$ and $\mathrm{Zn}$ ) were determined. Batch adsorption experiments were carried out at room temperature $\left(20 \pm 5^{\circ} \mathrm{C}\right)$.

The established quantity of adsorbent material was put into contact with $100 \mathrm{~mL}$ of synthetic solution of metals in $250 \mathrm{~mL}$ conical flasks for $24 \mathrm{~h}$ at the $\mathrm{pH}$ values established before, respectively 3,5 and 7 . The flasks were then shaken in a mechanical shaker, and the samples were collected at prefixed time intervals: $0,2,4,6,8$ and $24 \mathrm{~h}$. The samples were filtered after being collected through a $0.45 \mu \mathrm{m}$ Millipore filter prior to determining the concentration of adsorbed metal. For the characterization of initial and final solid samples, an Ethos Up Milestone microwave digestion system was used. 


\subsection{Calculation of Metal Ion Removal Efficiency (Wastewater Treatment Efficiency)}

The removal efficiency (\%) of metal ions was calculated using the following equation:

$$
\text { Removal efficiency }(\%)=\frac{\left(C_{0}-C_{e}\right)}{C_{0}} \times 100
$$

where:

$\mathrm{C}_{0}$ is the initial metal ion concentration $(\mathrm{mg} / \mathrm{L})$

$C_{e}$ is the equilibrium metal ion concentration $(\mathrm{mg} / \mathrm{L})$

\subsection{Isotherm Studies}

In order to highlight adsorption processes, certain mathematical models are used. Those most commonly accepted and used for applications in water and wastewater treatment are the Freundlich and Langmuir models [7].

The Langmuir and Freundlich adsorption models were used to mathematically describe the adsorption of the six metals onto the two adsorbent materials, both vegetable waste from sea buckthorn oil extraction technology.

\subsubsection{Langmuir Model}

The Langmuir model is presented in the form of the following equation:

$$
\frac{C_{e}}{Q_{e}}=\frac{1}{Q_{m} \times K_{L}}+\frac{C_{e}}{Q_{m}}
$$

where:

$C_{e}$ is the concentration at equilibrium $(\mathrm{mg} / \mathrm{L})$

$Q_{e}$ is the amount of metal adsorbed per gram of adsorbent at equilibrium $(\mathrm{mg} / \mathrm{g})$

$Q_{m}$ is the maximum adsorption capacity $(\mathrm{mg} / \mathrm{g})$

$Q_{m}$ and $K_{L}$ were obtained from the slope and intercept of the plots

$K_{L}$ is the Langmuir isotherm constant $(\mathrm{L} / \mathrm{mg})$

The Langmuir constants $Q_{m}$ and $K_{L}$ can be calculated from the slope and intercept of the linear plot of $\frac{C_{e}}{Q_{e}}$ versus $C_{e}$.

The essential characteristic of Langmuir isotherms can be expressed in terms of a dimensionless constant separation factor or equilibrium parameter $\left(R_{L}\right)$, which is described by the following equation:

$$
R_{L}=\frac{1}{\left(1+K_{L} \times C_{0}\right)}
$$

where:

$K_{L}$ is the Langmuir constant

$C_{0}$ is the initial concentration $(\mathrm{mg} / \mathrm{L})$

Terms:

if $R_{L}>1$, the value indicates that the process is unfavorable

if $R_{L}=1$, the value indicates that the process is linear

if $0<R_{L}<1$, the value indicates that the process is favorable

if $R_{L}=0$, the value indicates that the process is irreversible

\subsubsection{Freundlich Model}

The Freundlich equation linearized is:

$$
\log Q_{e}=\log K_{F}+\left(\frac{1}{n}\right) \log C_{e}
$$

where: 
$Q_{e}$ is the quantity of metal adsorbed by the adsorbent at equilibrium $(\mathrm{mg} / \mathrm{g})$

$C_{e}$ is the equilibrium concentration of the adsorbate $(\mathrm{mg} / \mathrm{L})$

$K_{F}$ and $n$ are Freundlich constants, with $K_{F}$ being the adsorption capacity of the adsorbent $(\mathrm{mg} / \mathrm{g})$ and $n$ giving an indication the favorability of the adsorption process

Values of $n>1$ represent favorable adsorption conditions. The Freundlich constants $K_{F}$ and $n$ can be calculated from the slope and intercept of the linear plot of $\log Q_{e}$ versus $\log C_{e}$.

\section{Results and Discussion}

\subsection{Characterization of Adsorbent Materials}

The chemical composition and structure of the adsorbent materials are presented in Table 2, and Figures 3 and 4. For the final physicochemical characterization of the adsorbent, the material resulting from the adsorption of metals from the $2 \mathrm{mg} / \mathrm{L}$ aqueous solution at $\mathrm{pH} 5$, where the removal efficiency was highest, was taken into account.

Table 2. Physical-chemical characterization of vegetable materials.

\begin{tabular}{ccccc}
\hline No. & Indicators & Units & P1 & P2 \\
\hline 1 & $\mathrm{pH}$ & $\mathrm{pH}$ unit. & 7.5 & 7.3 \\
2 & Dry matter & $\%$ & $95.03 \pm 1.90$ & $92.90 \pm 1.90$ \\
3 & Total organic carbon (TOC) & $\%$ d.m. & $49.34 \pm 1.18$ & $49.19 \pm 1.18$ \\
4 & Hydrogen & $\%$ d.m. & $6.63 \pm 0.37$ & $5.67 \pm 0.32$ \\
5 & Total nitrogen $\left(\mathrm{N}_{\mathrm{t}}\right)$ & $\%$ d.m. & $3.03 \pm 0.36$ & $2.94 \pm 0.35$ \\
\hline
\end{tabular}

d.m. = dry matter.

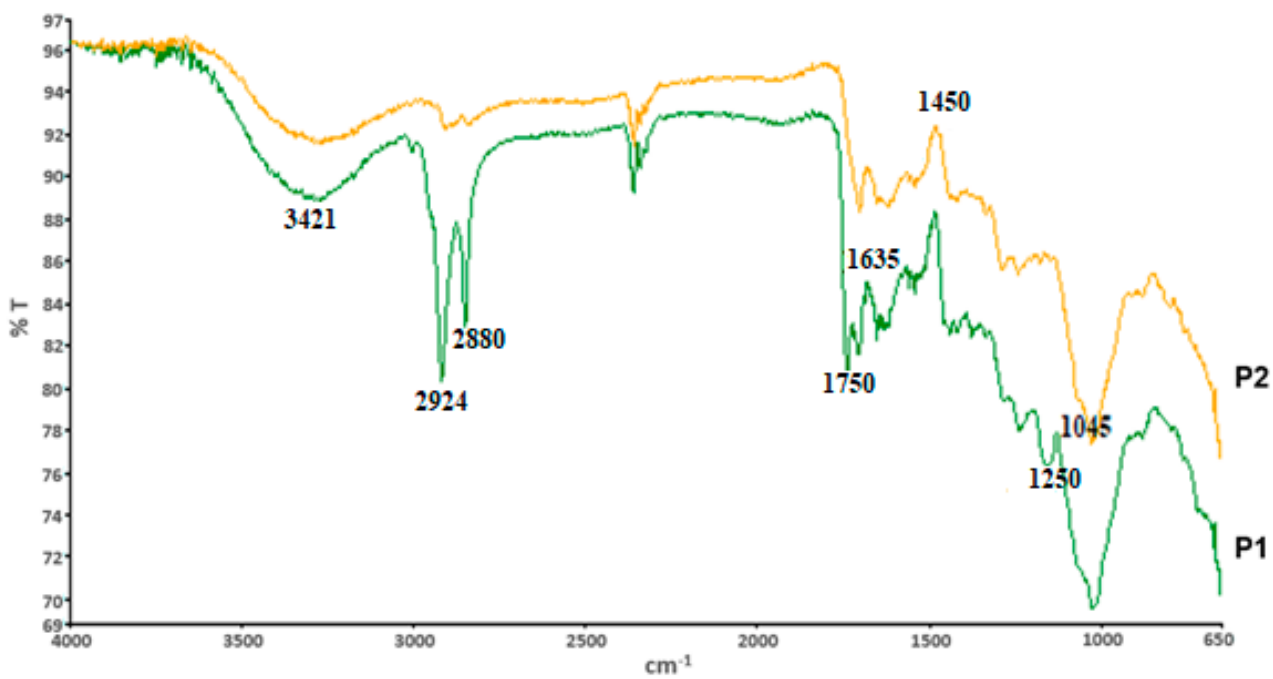

Figure 3. FTIR-ATR spectra of the activated adsorbent materials used in the adsorption of metals. 


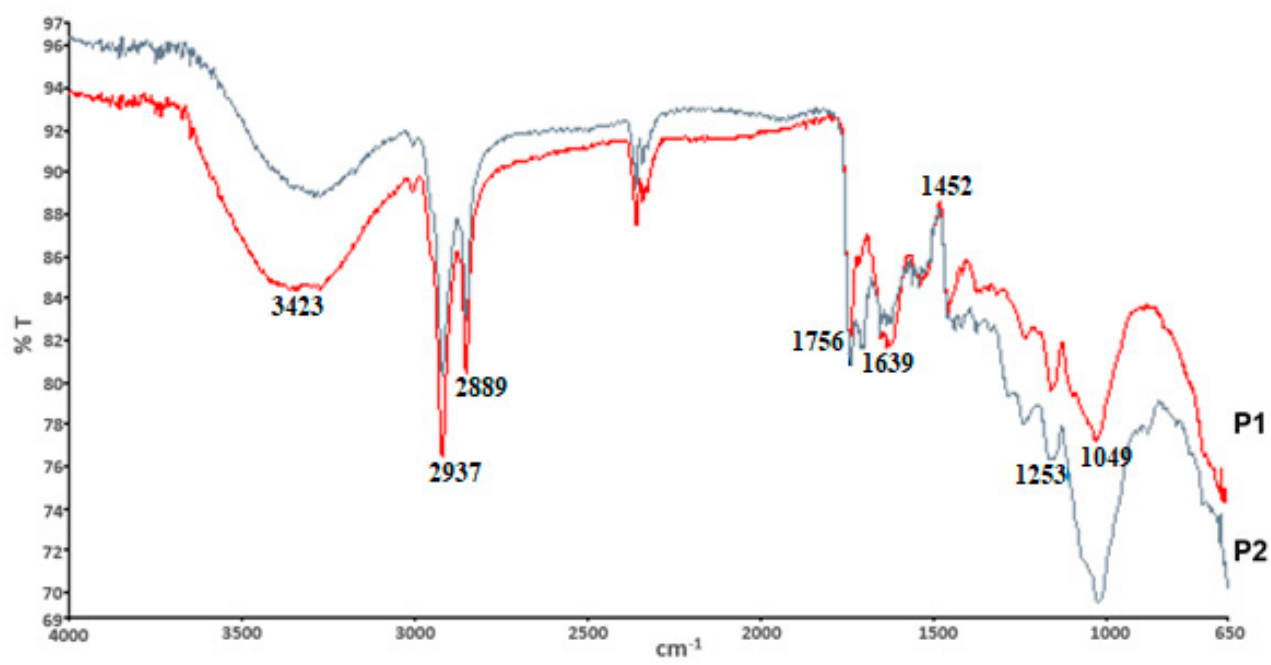

Figure 4. FTIR-ATR spectra of adsorbent materials used in the adsorption of metals from synthetic solution.

The solid materials were analyzed by Elemental Analysis, as shown in Table 1, to determine their composition in carbon, hydrogen and nitrogen. Vegetable materials contain cellulose, hemicellulose, lignin and many other compounds such as lipids, starch, hydrocarbons and simple proteins. The hydroxyl groups from the structure of these materials can ionize in aqueous medium and act as a weak acid cation exchanger.

The composition between the two materials is similar; only the technological process from which these materials comes differs: (a) the technological process of cold extraction of sea buckthorn oils (P2) and the process of hot extraction with organic solvents of sea buckthorn oil (P1).

\section{FTIR Analysis}

FTIR-ATR spectra can show the characteristic signals of the main organic components of vegetable waste: cellulose, lignin and hemicellulose [12].

Infrared spectral analysis allows for the identification of organic functional groups in vegetable waste and makes it possible to identify those involved in adsorption processes. In this study, FTIR-ATR spectra showed that several functional groups $\left(\mathrm{O}-\mathrm{H}\right.$ at $3421 \mathrm{~cm}^{-1}$, $\mathrm{C}-\mathrm{H}$ at $2924 \mathrm{~cm}^{-1}, \mathrm{~N}-\mathrm{H}$ at $1635 \mathrm{~cm}^{-1}$, etc.) present in vegetable materials play an important role in retaining $\mathrm{Cu}, \mathrm{Cr}, \mathrm{Co}, \mathrm{Ni}, \mathrm{Pb}$ and $\mathrm{Zn}$ ions on the surface of the adsorbent materials (Table 3).

Table 3. Main adsorption bands of the two types of adsorbent materials.

\begin{tabular}{ccc}
\hline $\begin{array}{c}\text { Functional } \\
\text { Grouaps }\end{array}$ & Materials before Adsorption $\boldsymbol{\vartheta} \mathbf{c m}^{-\mathbf{1}}$ & Materials after Adsorption $\boldsymbol{\vartheta} \mathbf{c m}^{-\mathbf{1}}$ \\
\hline O-H & 3421 and 3416 & 3423 and 3418 \\
$\mathbf{C}=\mathbf{C}$ & 3010 & 3011 \\
$\mathbf{C}-\mathbf{H}$ & 2924 and 2880 & 2937 and 2889 \\
$\mathbf{C}=\mathbf{O}$ & 1750 & 1756 \\
$\mathbf{N}-\mathbf{H}$ & 1635 & 1639 \\
$\mathbf{C H}$ & 1450 & 1452 \\
$\mathbf{C}=\mathbf{H}$ & 1250 & 1253 \\
$\mathbf{C}-\mathbf{O}$ & 1045 & 1049 \\
\hline
\end{tabular}

From Table 3 and the analysis of Figures 3 and 4, the results present the largest displacements of the bands for the functional polar and nonpolar groups. The functional groups $\left(\mathrm{OH}, \mathrm{C}=\mathrm{C}, \mathrm{CH}, \mathrm{C}=\mathrm{O}, \mathrm{C}=\mathrm{H}, \mathrm{NH}, \mathrm{CH}_{2}, \mathrm{C}=\mathrm{H}\right.$ and $\mathrm{CO}$ ) present in the structure of vegetable materials were ionized under certain experimental conditions (in the adsorption 
studies) and interact with studied metal cations. The studied materials have the behavior of weak acid ion exchangers.

After the adsorption studies, the materials were dried at $40{ }^{\circ} \mathrm{C}$ for $24 \mathrm{~h}$ and analyzed by the FTIR-ATR technique to identify the main functional groups implied in the adsorption of metals on the materials' surfaces.

A major change was observed in the bands corresponding to the $\mathrm{O}-\mathrm{H}$ valence vibrations of the hydroxyl groups in cellulose and lignin, recorded at $3421 \mathrm{~cm}^{-1}$ and $3416 \mathrm{~cm}^{-1}$, respectively (after contamination with $\mathrm{Cu}, \mathrm{Pb}$ and $\mathrm{Zn}$ ions). Another change in bands could be observed at $2924 \mathrm{~cm}^{-1}$ (C-H valence vibration), which shifted to $2937 \mathrm{~cm}^{-1}$, indicating a proton exchange process during adsorption. Intense changes were identified in the bands at 1635 and $1604 \mathrm{~cm}^{-1}$ (after contamination with metal ions), which were attributed to $\mathrm{N}-\mathrm{H}$ valence vibrations in amide groups (Figure 3 ).

The FTIR-ATR spectra also highlighted the complexity of sea buckthorn waste, which involved characteristic peaks for ethers and lactones, $\mathrm{H}-\mathrm{OH}$ bonds and the extent of $\mathrm{N}-\mathrm{H}$, phenols, $\mathrm{C}=\mathrm{O}$ in esters, dicarboxylic acids and $\alpha$-amino acids, stretching vibrations and deformation of $\mathrm{C}-\mathrm{H}$ and $\mathrm{CH}_{2}$.

\subsection{Equilibrium Concentration}

The equilibrium concentrations of metal were analyzed from the aqueous system, after the system reached the equilibrium $(6 \mathrm{~h})$, at $\mathrm{pH}=5$, using $1 \mathrm{~g}$ and $0.5 \mathrm{~g}$ of adsorbent material for all three concentrations studied. The results for equilibrium concentration are presented in Table 4.

Table 4. Equilibrium concentration obtained for both adsorbent materials in different conditions of $\mathrm{Co}, \mathrm{Pb}$, and $\mathrm{Zn}$.

\begin{tabular}{cccccccc}
\hline \multirow{2}{*}{$\begin{array}{c}\text { Initial Metal } \\
\text { Concentration }\end{array}$} & \multirow{2}{*}{$\begin{array}{c}\text { Adsorbent Material } \\
(\mathbf{m g} / \mathrm{L})\end{array}$} & $\mathbf{g})$ & \multicolumn{3}{c}{ P1 Sample } & \multicolumn{3}{c}{ P2 Sample } \\
\cline { 3 - 8 } & & $\mathbf{C o}$ & $\mathbf{P b}$ & $\mathbf{Z n}$ & $\mathbf{C o}$ & $\mathbf{P b}$ & $\mathbf{Z n}$ \\
\cline { 3 - 8 } & $\mathbf{0 . 5}$ & 0.71 & 1.10 & 0.77 & 0.52 & 0.49 & 0.62 \\
$\mathbf{2}$ & $\mathbf{1}$ & 0.53 & 0.32 & 0.54 & 0.19 & 0.17 & 0.43 \\
& $\mathbf{0 . 5}$ & 1.61 & 1.32 & 1.65 & 1.42 & 1.21 & 1.59 \\
$\mathbf{4}$ & $\mathbf{1}$ & 1.17 & 1.09 & 1.28 & 1.03 & 1.02 & 1.21 \\
& $\mathbf{0 . 5}$ & 2.61 & 2.62 & 2.67 & 2.19 & 2.11 & 2.51 \\
$\mathbf{6}$ & $\mathbf{1}$ & 2.29 & 2.23 & 2.34 & 2.01 & 2.06 & 2.14 \\
\hline
\end{tabular}

As can be seen from both Tables 4 and 5, the sample $\mathbf{P} 2$ reached the equilibrium very quickly compared with sample P1. When $1 \mathrm{~g}$ of adsorbent material is used, the equilibrium concentration is reached very quickly, as can be seen from Tables 4 and 5 .

Table 5. Equilibrium concentration obtained for both adsorbent materials in different conditions of $\mathrm{Cu}, \mathrm{Cr}$, and $\mathrm{Ni}$.

\begin{tabular}{ccccccccc}
\hline \multirow{2}{*}{$\begin{array}{c}\text { Initial Metal } \\
\text { Concentration } \\
(\mathbf{m g} / \mathrm{L})\end{array}$} & $\begin{array}{c}\text { Adsorbent Material } \\
\mathbf{( g )}\end{array}$ & \multicolumn{4}{c}{ Equilibrium Concentration (mg/L) } \\
\cline { 3 - 8 } & & $\mathbf{C u}$ & $\mathbf{C r}$ & $\mathbf{N i}$ & $\mathbf{C u}$ & $\mathbf{C r}$ & $\mathbf{N i}$ \\
\cline { 3 - 8 } & $\mathbf{0 . 5}$ & 1.16 & 1.19 & 0.80 & 0.52 & 0.69 & 0.74 \\
$\mathbf{2}$ & $\mathbf{1}$ & 0.51 & 0.60 & 0.65 & 0.18 & 0.46 & 0.49 \\
& $\mathbf{0 . 5}$ & 1.52 & 1.68 & 1.70 & 1.37 & 1.60 & 1.65 \\
$\mathbf{4}$ & $\mathbf{1}$ & 1.15 & 1.33 & 1.37 & 1.09 & 1.25 & 1.26 \\
& $\mathbf{0 . 5}$ & 2.59 & 2.69 & 2.71 & 2.32 & 2.53 & 2.56 \\
$\mathbf{6}$ & $\mathbf{1}$ & 2.27 & 2.36 & 2.39 & 2.05 & 2.17 & 2.19 \\
\hline
\end{tabular}

Therefore, the two types of vegetable waste can be considered competitive adsorbent materials for the removal of metals from contaminated wastewater. 


\subsection{Effect of $p H$}

In this study, we evaluated the following parameters: the solution $\mathrm{pH}$, contact time, initial concentration of the metals solution and adsorption isotherms.

For assessment of the $\mathrm{pH}$, synthetic aqueous solutions were used with $2 \mathrm{mg} / \mathrm{L}$ metal content and two different quantities of adsorbent material: 1 and $0.5 \mathrm{~g} / 100 \mathrm{~mL}$, respectively. The most representative results regarding wastewater treatment efficiency (removal efficiency) are presented in Figures 5 and 6.

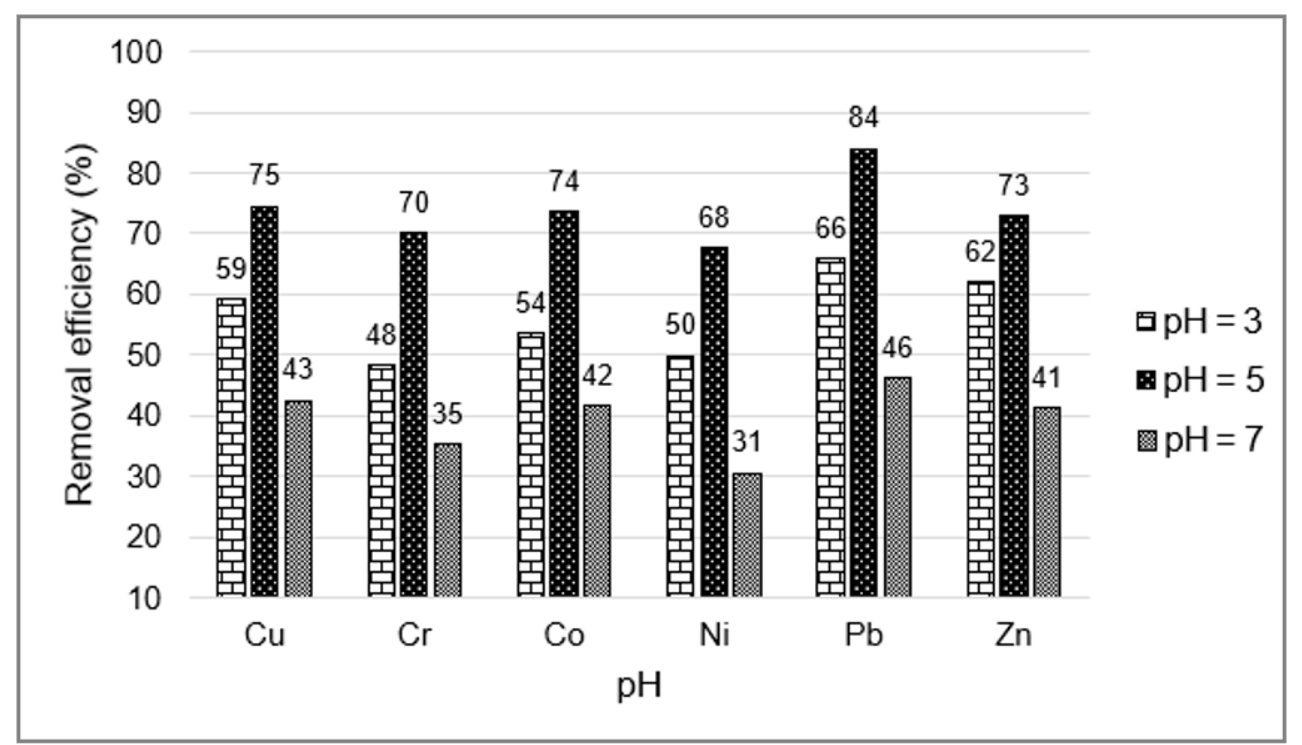

Figure 5. Effect of $\mathrm{pH}$ on metal removal efficiency using the P1 sample. (metal concentration: $2 \mathrm{mg} / \mathrm{L}$; adsorbent dosage: $1.0 \mathrm{~g} / 100 \mathrm{~mL}$ )

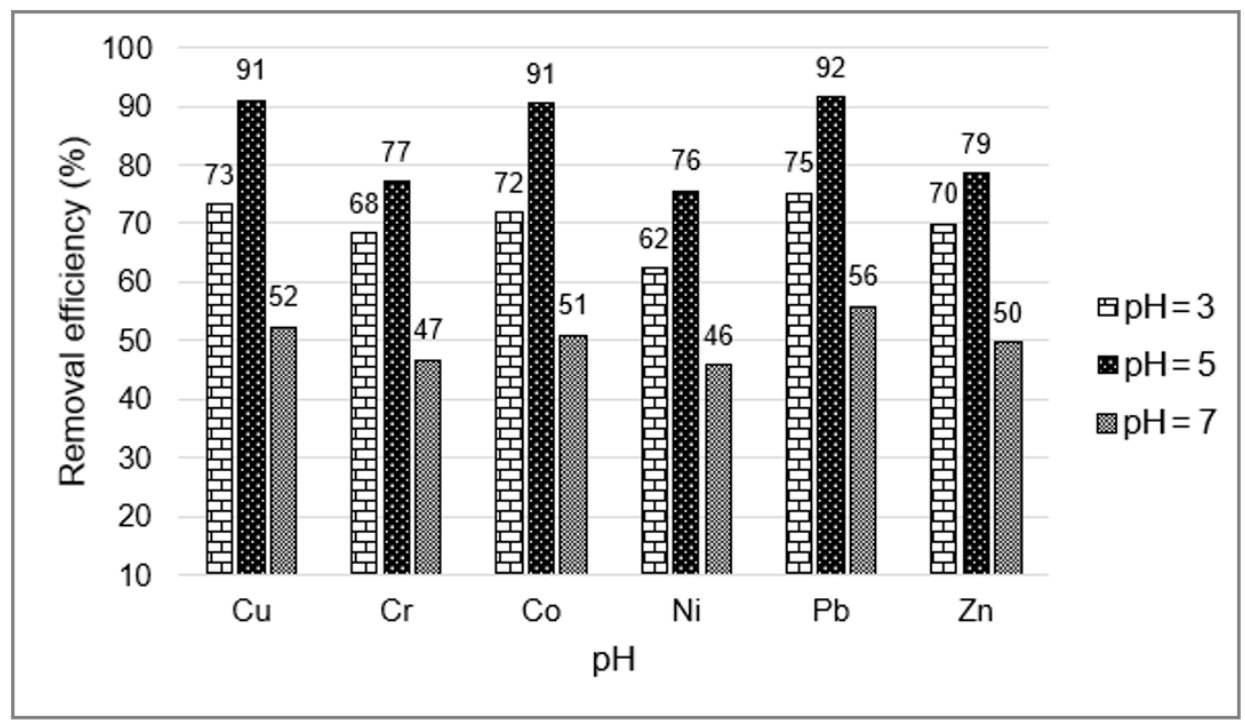

Figure 6. Effect of $\mathrm{pH}$ on metal removal efficiency using the P2 sample. (metal concentration: $2 \mathrm{mg} / \mathrm{L}$; adsorbent dosage: $1.0 \mathrm{~g} / 100 \mathrm{~mL}$ ).

From Figures 5 and 6, it can be observed that the best removal efficiency was recorded at $\mathrm{pH} 5$ for both samples. For the P1 adsorbent material, removal efficiency was $68-84 \%$. For P2, an increase of almost 10\% was observed, the removal efficiency being 77-92\%. The removal efficiency of $\mathrm{Co}, \mathrm{Cu}$ and $\mathrm{Pb}$ was over $90 \%$ for $\mathrm{P} 2$, indicating good properties of this material to retain toxic heavy metals from liquid effluents. At $\mathrm{pH} 3$, efficiency was $48-66 \%$ for P1 and $62-75 \%$ for P2. It was observed that at $\mathrm{pH} 7$, removal efficiency was 
lower, in the range $31-46 \%$ for $\mathrm{P} 1$ and $46-56 \%$ for P2. Removal efficiency decreased when the $\mathrm{pH}$ value increased to 7 and the equilibrium concentration increased. Given that the two adsorbent materials come from different technological processes, it is observed that the metal removal efficiency is different for the two samples. Thus, for sample P2 (sea buckthorn waste from cold pressing extraction), the metal removal efficiency is higher than for sample P1 (sea buckthorn waste from extraction with organic solvents).

At alkaline $\mathrm{pH}$, metal ions transform into soluble hydroxylated complexes and hydroxide forms and subsequently precipitate [7]. Therefore, metal removal efficiency is optimal only at low $\mathrm{pH}$ ( 3 and 5). As a function of $\mathrm{pH}$ value, the surface of the adsorbent material presents a negative or positive charge. The removal of metals from an aqueous solution by adsorption is highly dependent on the initial solution's $\mathrm{pH}$, which determines the charge in the surface of the adsorbent material, the degree of ionization and the oxidation state of the adsorbed element.

When using a smaller amount of adsorbent material $(0.5 \mathrm{~g})$, the metals' removal efficiency from synthetic wastewater solutions was lower in comparison with $1 \mathrm{~g}$ of adsorbent material.

From the results obtained, it can be concluded that an increase in the amount of adsorbent material leads to an increase in the metals' removal efficiency from synthetic wastewater solutions.

\subsection{Effect of Contact Time and Initial Metals Concentration}

The negative or positive charge on the surface of an adsorbent is usually influenced by contact time [7]. Thus, the effect of contact time was evaluated to determine the moment when the state of equilibrium was attained, as a stage prior to studying the kinetics of metal adsorption. The nature of the removal process depends on the retention duration.

The equilibrium concentration was studied in the range 2-24 h. After $6 \mathrm{~h}$ from the beginning of the batch adsorption studies, equilibrium conditions were obtained.

As with $\mathrm{pH}$, for assessment of the effect of contact time, synthetic solutions of wastewater were used, with 2,4 and $6 \mathrm{mg} / \mathrm{L}$ of metal content and two different quantities of adsorbent material: $0.5 \mathrm{~g}$ and $1 \mathrm{~g} / 100 \mathrm{~mL}$, respectively. The most representative results regarding the influence of contact time and initial metals concentration on the removal process are presented in Figures 7 and 8.

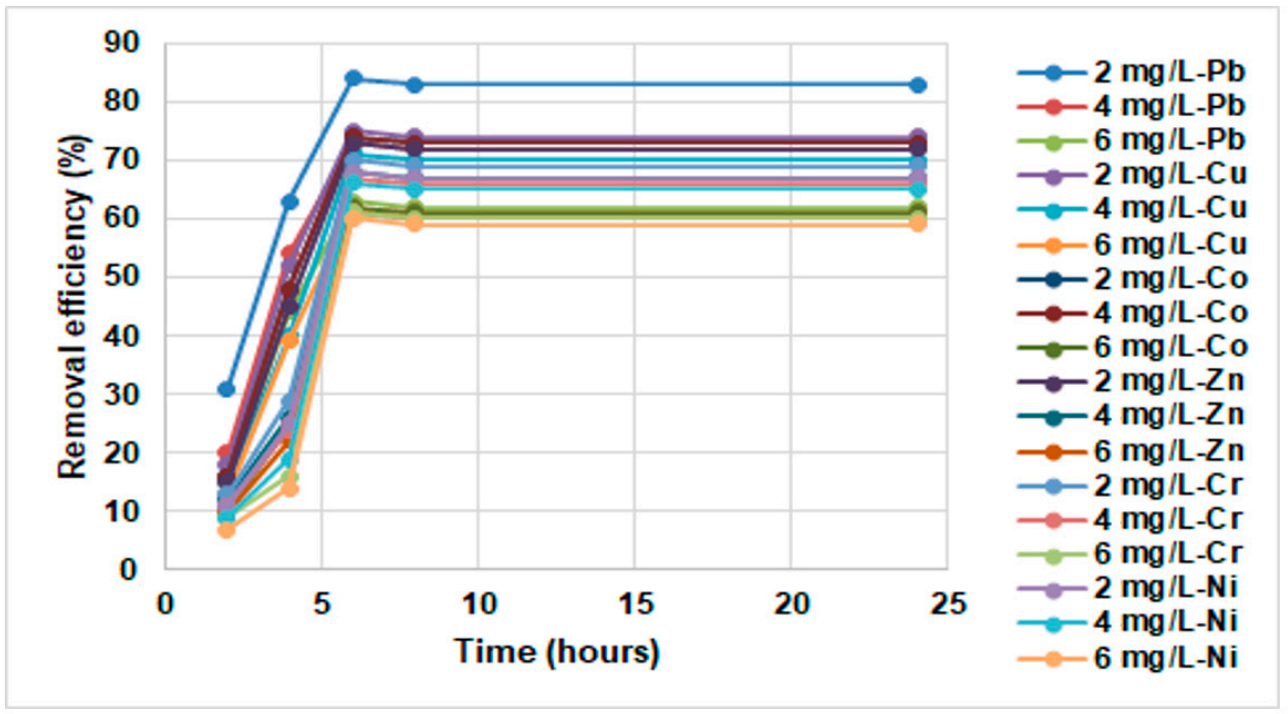

Figure 7. Effect of contact time and initial metals concentration on metals removal efficiency using the P1 sample (Conditions: $2 \mathrm{mg} / \mathrm{L}, 4 \mathrm{mg} / \mathrm{L}$ and $6 \mathrm{mg} / \mathrm{L}, 1.0 \mathrm{~g} / 100 \mathrm{~mL}$ at $\mathrm{pH}$ 5). 


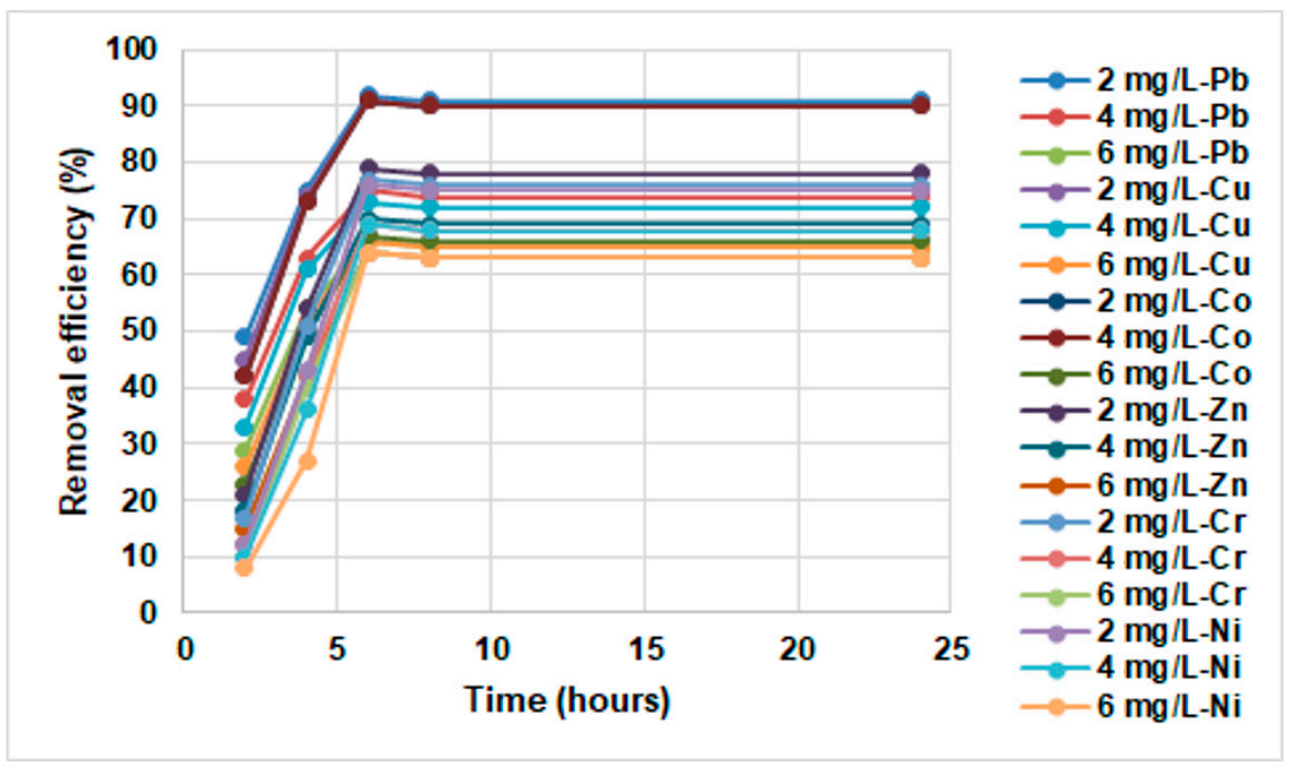

Figure 8. Effect of contact time and initial metals concentration on metals removal efficiency using the P2 sample (Conditions: $2 \mathrm{mg} / \mathrm{L}, 4 \mathrm{mg} / \mathrm{L}$ and $6 \mathrm{mg} / \mathrm{L}, 1.0 \mathrm{~g} / 100 \mathrm{~mL}$ at $\mathrm{pH}$ 5).

As can be seen from Figures 6 and 7, the state of equilibrium was achieved after 6 $\mathrm{h}$, when the maximum metals removal efficiency was achieved. Thus, the charge on the surface of the two adsorbent materials are greatly influenced by contact time.

Based on the results obtained, it can be observed that if the concentration of metals in the solution is higher, the removal efficiency is lower (Figures 6 and 7). However, for the three heavy metal concentrations studied, removal efficiency was above $60 \%$. This could be an argument for removal efficiency reaching up to $60 \%$ even in experiments where there is a lower amount of adsorbent material compared with the metal concentration in effluents subject to treatment. The best removal efficiency was obtained at $2 \mathrm{mg} / \mathrm{L}$ and $\mathrm{pH} 5$ for all metals studied.

After six hours from the beginning of the batch experiments, the following order of metals removal efficiency was obtained for the P1 sample at $2 \mathrm{mg} / \mathrm{L}$ of initial metal concentration: $\mathrm{Pb}(84 \%)>\mathrm{Cu}(74 \%)>\mathrm{Co}(73 \%)>\mathrm{Zn}(72 \%)>\mathrm{Cr}(70 \%)>\mathrm{Ni}(67 \%)$.

The order of metal removal efficiency for the $\mathrm{P} 2$ sample was as follows: $\mathrm{Pb}(92 \%)>\mathrm{Cu}$ $(91 \%)>\mathrm{Co}(91 \%)>\mathrm{Zn}(77 \%)>\mathrm{Cr}(77 \%)>\mathrm{Ni}(76 \%)$. Both adsorbent materials have similar behaviors in terms of metal removal efficiency, the only difference between the materials being their source.

Based on the results obtained regarding the effect of the parameters $\mathrm{pH}$, contact time and amount of adsorbent material, in subsequent experiments, $1 \mathrm{~g}$ of adsorbent material, $6 \mathrm{~h}$ of contact time and $\mathrm{pH} 5$ were used.

The saturation state was recorded after $24 \mathrm{~h}$ from the beginning of the experiments for both adsorbent materials.

The authors need to minimize operating costs in order to develop and implement a sustainable strategy for the remediation of heavy metal pollution of wastewater at laboratory level. For this reason, these materials will not be regenerated because it requires a high operating cost. The adsorbent materials used in this study will continue to be reused in the context of the circular economy as biofuel materials after the palletizing and briquetting process for combustion plants.

The company that made dietary supplements generates 1.6 tons of vegetable waste per year. This waste must be recovered very quickly, so that the company can be helped to get rid of this waste. 


\subsection{Adsorption Results (Isotherm)}

The adsorption of metals between the two phases (solid/liquid) is a measure of the equilibrium that can be revealed based on adsorption isotherms. The equilibrium data were analyzed using the Langmuir and Freundlich isotherm models to obtain the most appropriate mathematical model to characterize the entire adsorption process. Isotherms were evaluated based on linear regression by estimating the correlation coefficients. The linear profile of the Langmuir isotherm was obtained by graphical representation of the $\mathrm{Ce} / \mathrm{Qe}$ ratio versus $\mathrm{Ce}$ (Figures 9 and 10).

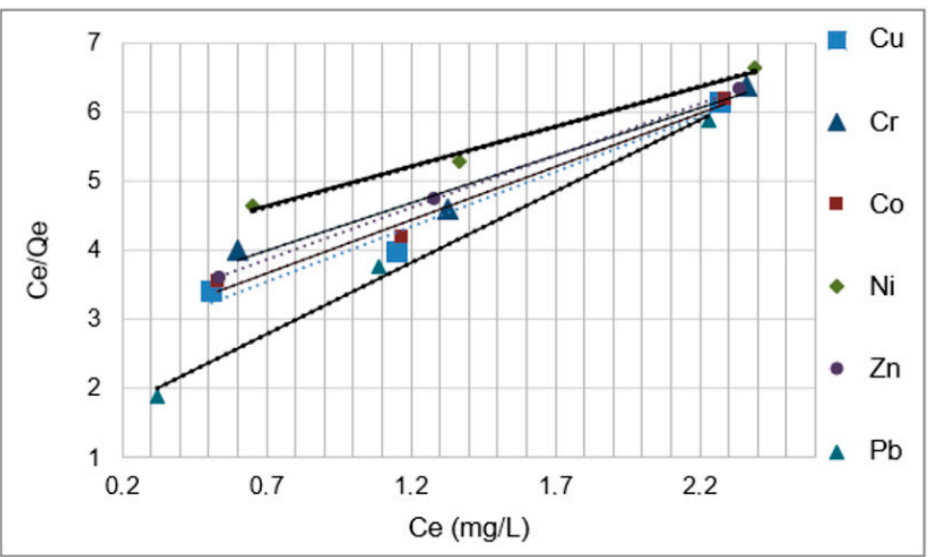

Figure 9. Plot of the Langmuir model for P1.

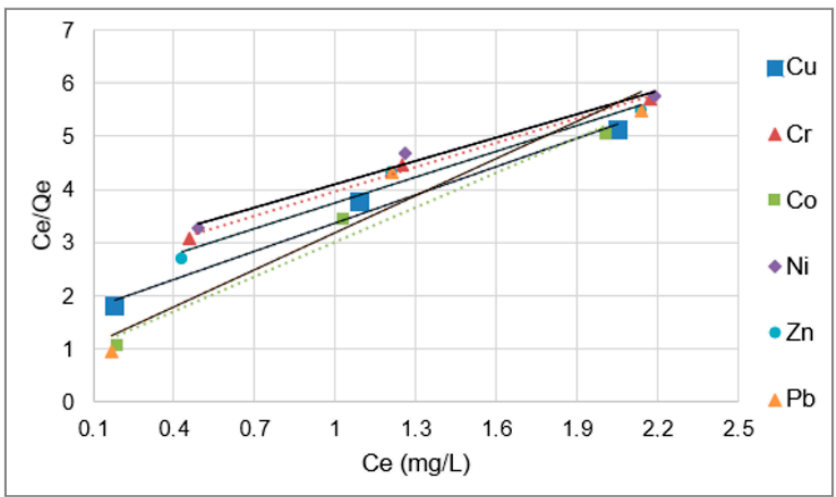

Figure 10. Plot of the Langmuir model for P2.

The constant separation factor of the Langmuir isotherm model is presented in Tables 6 and 7.

Table 6. $\mathrm{R}_{\mathrm{L}}$ value of the metals in the Langmuir isotherm for the P1 sample.

\begin{tabular}{cccccccc}
\hline \multirow{2}{*}{ Initial Metal Concentration (mg/L) } & \multicolumn{7}{c}{$\mathbf{R}_{\mathbf{L}}$ Value } \\
\cline { 2 - 8 } & $\mathbf{P b}$ & $\mathbf{C u}$ & $\mathbf{C r}$ & $\mathbf{C o}$ & $\mathbf{N i}$ & $\mathbf{Z n}$ \\
\hline 2 & 0.2738 & 0.1588 & 0.1421 & 0.1621 & 0.1142 & 0.1404 \\
4 & 0.1586 & 0.0862 & 0.0765 & 0.0882 & 0.0605 & 0.0755 \\
6 & 0.1116 & 0.0592 & 0.0523 & 0.0606 & 0.0412 & 0.0516 \\
\hline
\end{tabular}


Table 7. $\mathrm{R}_{\mathrm{L}}$ value of the metals in the Langmuir isotherm for the P2 sample.

\begin{tabular}{cccccccc}
\hline \multirow{2}{*}{ Initial Metal Concentration $(\mathbf{m g} / \mathbf{L})$} & \multicolumn{6}{c}{$\mathbf{R}_{\mathbf{L}}$ Value of Metals } \\
\cline { 2 - 8 } & $\mathbf{P b}$ & $\mathbf{C u}$ & $\mathbf{C r}$ & $\mathbf{C o}$ & $\mathbf{N i}$ & $\mathbf{Z n}$ \\
\hline 2 & 0.2420 & 0.2384 & 0.1712 & 0.2454 & 0.1587 & 0.1910 \\
4 & 0.1377 & 0.1354 & 0.0936 & 0.1398 & 0.0862 & 0.1056 \\
6 & 0.0962 & 0.0945 & 0.0644 & 0.0978 & 0.0592 & 0.0730 \\
\hline
\end{tabular}

The Langmuir constant $\mathrm{R}_{\mathrm{L}}$ is in the range $0-1$, indicating that the retention of metal ions is favorable. Adsorption is favorable for values between $0.1<1 / \mathrm{n}<1.0$ for both adsorption materials, as can be seen in Tables 6 and 7 for all the initial metal concentrations studied.

Applicability of the Freundlich isotherm was evaluated by graphical representation of $\log Q e$ versus $\log C e$ values (Figures 11 and 12).

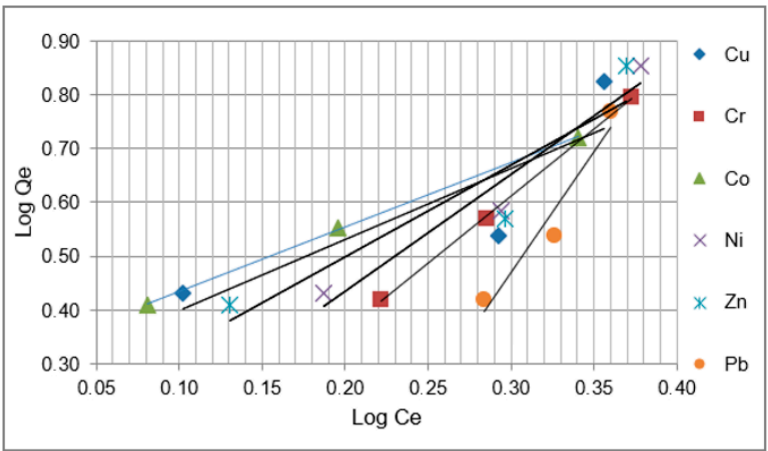

Figure 11. Plot of the Freundlich model for P1.

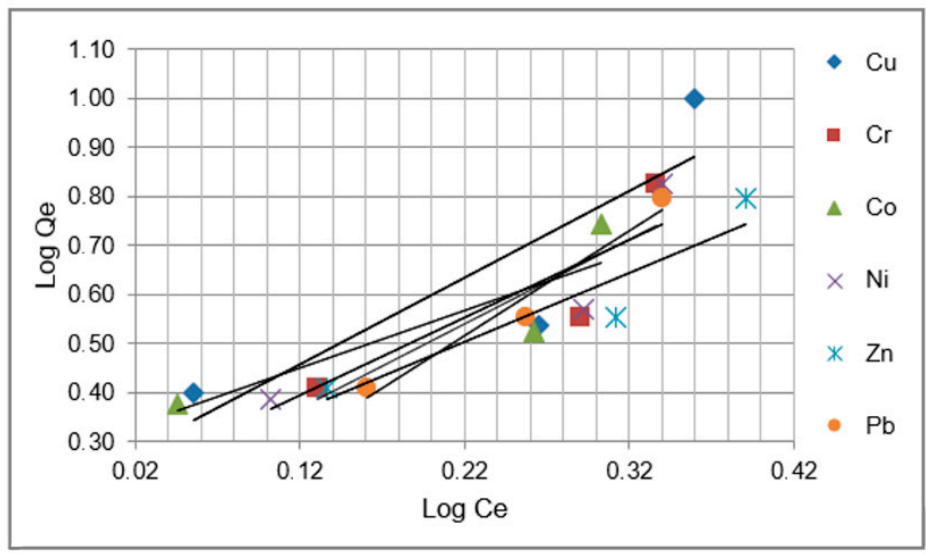

Figure 12. Plot of the Freundlich model for P2.

The values of the correlation coefficients of the Langmuir model were higher compared with the Freundlich model values, indicating that adsorption results can be statistically processed with the Langmuir model.

The parameters of the Langmuir isotherm were determined graphically from the slope $(\mathrm{Qm})$ and intercept $\left(\mathrm{K}_{\mathrm{L}}\right)$ of the graphical representation $\mathrm{Ce} / \mathrm{Qe}=f(\mathrm{Ce})$.

The parameters of the Freundlich isotherm were determined graphically from the slope $\left(K_{\mathrm{F}}\right)$ and intercept $(1 / \mathrm{n})$ of the graphical representation $\log Q e=f(\log C e)$.

The isotherm parameters of the Langmuir and Freundlich models are shown in Table 8 (P1) and Table 9 (P2). 
Table 8. Isotherm parameters for $\mathrm{Pb}, \mathrm{Cu}, \mathrm{Cr}, \mathrm{Co}, \mathrm{Ni}$ and $\mathrm{Zn}$ adsorption onto the $\mathrm{P} 1$ sample.

\begin{tabular}{ccccccc}
\hline & \multicolumn{3}{c}{ Langmuir Isotherm Model } & \multicolumn{2}{c}{ Freundlich Isotherm Model } \\
\hline Metal & $\mathbf{K}_{\mathbf{L}} \mathbf{( L / g )}$ & $\mathbf{Q m} \mathbf{( m g / g )}$ & $\mathbf{R}^{\mathbf{2}}$ & $\left.\mathbf{K}_{\mathbf{F}} \mathbf{( m g} / \mathbf{g}\right)$ & $\mathbf{1 / n}$ & $\mathbf{R}^{\mathbf{2}}$ \\
\hline $\mathrm{Pb}$ & 1.33 & 13.56 & 0.9920 & 1.41 & 0.18 & 0.9639 \\
$\mathrm{Cu}$ & 2.65 & 9.72 & 0.9529 & 1.83 & 0.10 & 0.7586 \\
$\mathrm{Cr}$ & 3.02 & 10.06 & 0.9655 & 2.49 & 0.14 & 0.8275 \\
$\mathrm{Co}$ & 2.58 & 11.57 & 0.9756 & 1.20 & 0.31 & 0.7751 \\
$\mathrm{Ni}$ & 3.88 & 8.33 & 0.9723 & 1.55 & 0.21 & 0.8275 \\
$\mathrm{Zn}$ & 3.06 & 10.53 & 0.9919 & 1.71 & 0.16 & 0.8751 \\
\hline
\end{tabular}

Table 9. Isotherm parameters for $\mathrm{Pb}, \mathrm{Cu}, \mathrm{Cr}, \mathrm{Co}, \mathrm{Ni}$ and $\mathrm{Zn}$ adsorption onto the $\mathrm{P} 2$ sample.

\begin{tabular}{ccccccc}
\hline & \multicolumn{3}{c}{ Langmuir Isotherm Model } & \multicolumn{2}{c}{ Freundlich Isotherm Model } \\
\hline Metal & $\mathbf{K}_{\mathbf{L}}(\mathbf{L} / \mathbf{g})$ & $\mathbf{Q}(\mathbf{m g} / \mathbf{g})$ & $\mathbf{R}^{\mathbf{2}}$ & $\mathbf{K}_{\mathbf{F}}(\mathbf{m g} / \mathbf{g})$ & $\mathbf{1 / n}$ & $\mathbf{R}^{\mathbf{2}}$ \\
\hline $\mathrm{Pb}$ & 1.57 & 16.25 & 0.9960 & 1.54 & 0.23 & 0.9946 \\
$\mathrm{Cu}$ & 1.60 & 11.00 & 0.9713 & 1.76 & 0.25 & 0.8598 \\
$\mathrm{Cr}$ & 2.42 & 11.46 & 0.9955 & 1.73 & 0.16 & 0.9951 \\
$\mathrm{Co}$ & 1.54 & 12.91 & 0.9826 & 1.18 & 0.31 & 0.9367 \\
$\mathrm{Ni}$ & 2.65 & 10.87 & 0.9874 & 1.59 & 0.20 & 0.9491 \\
$\mathrm{Zn}$ & 2.12 & 12.19 & 0.9999 & 1.41 & 0.19 & 0.8598 \\
\hline
\end{tabular}

The values of $1 / \mathrm{n}$ (Tables 8 and 9) were lower than 1 , revealing that all six metals were efficiently removed using both adsorbent materials.

The comparison of coefficient of correlation $\left(\mathrm{R}^{2}\right)$ indicates that the Langmuir isotherm achieved more satisfactory results $\left(R^{2}=0.9874\right.$ to 0.9999$)$ compared with the Freundlich isotherm $\left(\mathrm{R}^{2}=0.7551\right.$ to 0.9946$)$ for the adsorption of metals onto both types of vegetable waste.

The adsorbent materials used in this research are cheap and easy to obtain (from the technological process of obtaining sea buckthorn oil); for these reasons, they do not need to be regenerated and reused in other adsorption steps.

These materials will be dried and transformed by the pelletizing process into fuels for combustion plants in the context of the circular economy. This study proposed a way to remove heavy metals and to valorize vegetable waste as adsorbent materials for wastewater treatment.

\section{Conclusions}

The paper focused on the valorization of solid waste from the sea buckthorn oil industry as a potential adsorbent of metals $(\mathrm{Cu}, \mathrm{Cr}, \mathrm{Co}, \mathrm{Ni}, \mathrm{Pb}$ and $\mathrm{Zn}$ ) from wastewater. The removal efficiency of the adsorbent materials (P1 and P2 samples) increased as the initial concentration of metals increased from 2 to $6 \mathrm{mg} / \mathrm{L}$. $\mathrm{pH}$ is an important parameter influencing the removal efficiency of metals from aqueous solutions. When the value of $\mathrm{pH}$ is higher ( 7 unit.pH), the efficiency is slower because the functional groups (hydroxyls and amines) on the surface of the adsorbent materials are blocked. The optimal $\mathrm{pH}$ for metals removal efficiency was $\mathrm{pH} 5$ due to the functional groups of the adsorbent materials described by FTIR-ATR characterization.

The state of equilibrium for all adsorption studies was achieved after $6 \mathrm{~h}$. The Langmuir constant $R_{L}$ is in the range $0-1$, indicating that the retention of metal ions is favorable, and this model describes the adsorption process very well. The difference between samples P1 (92\%) and P2 (84\%) in the efficiency of metal removal is not significant, and both materials can be considered promising for the removal of metals from wastewater and for compliance with NTPA 001/2005.

At the same time, recovery of this waste as material for adsorbing toxic metals from wastewater can be a target in the move towards a circular economy and could minimize environmental pollution and associated health risks. 
Author Contributions: L.K., G.C. and M.P. Methodology; G.-A.C., V.S. and C.I.C. Investigation. All authors have read and agreed to the published version of the manuscript.

Funding: This research received no external funding.

Institutional Review Board Statement: Not applicable.

Informed Consent Statement: Not applicable.

Data Availability Statement: Not applicable.

Acknowledgments: This work was carried out through the Nucleu Program financed by the Ministry of Research and Innovation (contract No. 20N/2019, project code PN 190404 01).

Conflicts of Interest: The authors declare no conflict of interest.

\section{References}

1. Abdel-Ghani, N.; Hefny, M.; El-Chaghaby, G.A. Removal of lead from aqueous solution using low cost abundantly available adsorbents. Int. J. Environ. Sci. Technol. 2007, 4, 67-73. [CrossRef]

2. Argun, M.E.; Dursun, S. A new approach to modification of natural adsorbent for heavy metal adsorption. Bioresour. Technol. 2008, 99, 2516-2527. [CrossRef] [PubMed]

3. Chiban, M.; Soudani, A.; Eddaoudi, H.; Sinan, F.; Persin, M. Wastewater treatment by adsorption onto Carpobrotus edulis used as natural adsorbent. In Proceedings of the 13th IWRA World Water Congress, Montpellier, France, 1-4 September 2008; pp. 1-4.

4. Kula, I.; Uğurlu, M.; Karaoğlu, H.; Celik, A. Adsorption of Cd (II) ions from aqueous solutions using activated carbon prepared from olive stone by $\mathrm{ZnCl}_{2}$ activation. Bioresour. Technol. 2008, 99, 492-501. [CrossRef] [PubMed]

5. Pascu, D.E.; Alina Traistaru, G.; Nechifor, A.C.; Raluca Miron, A. Iron and manganese removal from drinking water. J. Electrochem. Sci. Eng. 2016, 6, 47-55. [CrossRef]

6. Saeed, A.; Akhter, M.W.; Iqbal, M. Removal and recovery of heavy metals from aqueous solution using papaya wood as a new biosorbent. Sep. Purif. Technol. 2005, 45, 25-31. [CrossRef]

7. Shafiq, M.; Alazba, A.; Amin, M. Removal of heavy metals from wastewater using date palm as a biosorbent: A comparative review. Sains Malays. 2018, 47, 35-49.

8. Ahmaruzzaman, M. Industrial wastes as low-cost potential adsorbents for the treatment of wastewater laden with heavy metals. Adv. Colloid Interface Sci. 2011, 166, 36-59. [CrossRef] [PubMed]

9. Hubbe, M.A.; Hasan, S.H.; Ducoste, J.J. Cellulosic substrates for removal of pollutants from aqueous systems: A review. 1. Metals. BioResources 2011, 6, 2161-2287. [CrossRef]

10. Ince, M.; Ince, O.K. An overview of adsorption technique for heavy metal removal from water/wastewater: A critical review. Int. J. Pure Appl. Sci. 2017, 3, 10-19. [CrossRef]

11. Zhang, Y.; Zhao, J.; Jiang, Z.; Shan, D.; Lu, Y. Biosorption of Fe (II) and Mn (II) ions from aqueous solution by rice husk ash. Biomed. Res. Int. 2014, 2014, 973095. [CrossRef] [PubMed]

12. Bhatnagar, A.; Kaczala, F.; Hogland, W.; Marques, M.; Paraskeva, A.C.; Papadakis, G.V.; Silanpaa, M. Valorization of solid waste products from olive oil industry as potential adsorbents for water pollution control-A review. Environ. Sci. Pollut. Res. 2014, 21, 268-298. [CrossRef] [PubMed]

13. Kim, L.; Vasile, G.; Stanescu, B.; Calinescu, S.; Batrinescu, G. Distribution and bioavailability of mobile arsenic in sediments from a mining catchment area. J. Environ. Prot. Ecol. 2015, 16, 1307-1315.

14. Kim, L.; Vasile, G.; Stanescu, B.; Dinu, C.; Ene, C. Distribution of trace metals in surface water and streambed sediments in the vicinity of an abandoned gold mine from Hunedoara County, Romania. Rev. Chim. 2016, 67, 1441-1446.

15. Vardhan, K.H.; Kumar, P.S.; Panda, R.C. A review on heavy metal pollution, toxicity and remedial measures: Current trends and future perspectives. J. Mol. Liq. 2019, 290, 1-22. [CrossRef]

16. Wang, X.S.; Li, Z.Z.; Tao, S.R. Removal of chromium (VI) from aqueous solution using walnut hull. J. Environ. Manag. 2009, 90, 721-729. [CrossRef] [PubMed]

17. HG 352/2005. Government Decision Regarding the Modification and Completion of Government Decision No. 188/2002 for the Approval of Some Norms on the Conditions for Discharging Wastewater into the Aquatic Environment. Available online: https:/ / ec.europa.eu/neighbourhood-enlargement/sites/near/files/pdf/fiche-projet/romania/ro-fm/2006/2006-01 7-1470303/annex-5---list-of-relevant-laws-and-regulations.pdf (accessed on 25 January 2020).

18. Babarinde, N.A.; Babalola, J.O.; Sanni, S.O. Isotherm and thermodynamic studies of the biosorption of Cd (II) from solution by maize leaf. Int. J. Phys. Sci. 2007, 2, 207-211.

19. Popescu, M.; Danciu, T.; Danciu, E.; Ivopol, G. Seabuckthorn oil extraction, a model for solid-liquid extraction process. UPB Sci. Bull. Ser. B 2013, 75, 35-42.

20. Popescu, M.; Danciu, T.; Danciu, E.; Ivopol, G.; Manea, S. Natural antioxidants, free-radical-scavengers and minerals, in fresh juices and vegetables. Rev. Chim. 2011, 62, 761-765. 
21. Jagung, P.T. Removal of Zn (II), Cd (II) and Mn (II) from aqueous solutions by adsorption on maize stalks. Malays. J. Anal. Sci. 2011, 15, 8-21.

22. Mengistie, A.A.; Rao, T.S.; Rao, A.P. Adsorption of Mn (II) ions from wastewater using activated carbon obtained from birbira (Militia ferruginea) leaves. Glob. J. Inc. 2012, 12, 4-12. 